in the hope that they will check up on some of my translations and tell me of my mistakes." If this quotation suggests indulgence in a kind of odium theologicum, it is misleading. Waley was fully aware of what he was "up to" and of what specialists are "up to"; and he acknowledges frequently and generously the help of specialists, as many of them acknowledge his. He was equipped for his work as a scholar with a superb literary memory and an unusually complete linguistic mastery; but he lacked one common characteristic of a scholar, the desire to say the "last word" on a topic-often, indeed, he was inclined to risk saying the first.

What was his success? Short of the dubiety of the "best-seller" but well beyond the succés d'estime of a coterie. Opinions and tastes differ greatly about the merit of his translations from Chinese poets, though all admit that he was an innovator; someone said that he had done more harm to English poetry than anyone else, and T. S. Eliot said that he was no poet. But such judgements are a kind of de facto recognition of power; and no one will deny that his prose translations, except when deliberately literal, are wonderfully free from "translationese". As for the later books, if anyone in England or the United States feels that he knows something about life in China in the time of the poets Li Po, Po Chu-i, and Yuan Mei, if he has reached at least some degree of detachment about the Opium War or the activities of Stein and Pelliot at Tun-huang, some degree of understanding of the rigour rather than the vagueness of Indian and Chinese Buddhist logic, this person probably owes much to Waley. And there are certainly sinologues in various countries who have fruitfully taken up, as specialists, ideas thrown out by Waley.

I knew him only during the last ten years of his life. I would like to recall here one of a number of memories of his calm absorption in his studies. He came to stay with me for a few weeks in the late spring of 1958, when he was working on the texts for Ballads and Stories from Tun-huang (1960). He would sit out in the garden, equipped only with text and necessary stationery; and in the evenings he would share with us, reading aloud, a lot of material that had lain a few hours earlier buried in quite a difficult and often defective Chinese text. He carried his learning lightly with neither arrogance nor false modesty; and he held it always at the disposal of his juniors in the field with no trace either of impatience or of condescension.

Arthur David Waley was born in 1889 , and was educated at Rugby and at King's College, Cambridge. He was created C.B.E. in 1952, awarded the Queen's Medal for Poetry in 1953, and made a Companion of Honour in 1956. He was a Fellow of the British Academy, an honorary fellow of King's College, Cambridge, and of the School of Oriental and African Studies, and held honorary degrees at the universities of Aberdeen and Oxford.

WALTER ROBINSON.

\title{
DR. REUBEN LEVY
}

Reuben Levy was born in Manchester in April, 1891, and died in Cambridge in September, 1966.

The first and only Professor of Persian in Cambridge (the personal title was conferred upon him in 1949), Levy served his country in the armed forces in both wars, and thus gained 
a close acquaintance with the Middle East which enriched and diversified his learning in Arabic and Persian. Educated in North Wales and at Oxford, he briefly held a Persian Lectureship at Oxford from 1920 to 1923, crossed the Atlantic from 1923 to 1926, and then on the death of E. G. Browne, and the consequent succession of R. A. Nicholson to the Sir Thomas Adams's Chair, Levy was appointed Persian Lecturer in Cambridge in 1926. I count myself fortunate to have been one of his earliest pupils, and thereafter a lifelong friend.

Levy's contributions to Islamic studies were numerous, and all valuable. His bestknown work was the pioneering Sociology of Islam (2 vols., 1931-33), revised and re-issued as The Social Structure of Islam (1957). He displayed accuracy and originality of a high order as editor (Ma'älim al-qurba, 1938, and Qäbüs-näma, 1951), to which he added gracefulness and wit as a translator (Mirror for Princes, 1951, and The Tales of Marzuban, 1959). He also contributed to studies in Persian grammar and literature, and wrote many articles. He was a Fellow of the Royal Asiatic Society since 1927, and served on the Council. He characteristically described his recreations as "travelling, keeping alive"-the latter a modest reference to a long and cheerfully waged battle against ill health.

Levy was a gifted and enthusiastic teacher who never allowed erudition to overcome an innate gaiety. He was much admired and greatly loved by a large circle of friends and colleagues, many of whom were his former pupils.

A. J. Arberry. 